\title{
Protein Phosphatase 2A Catalytic Subunit $\alpha$ (PP2Ac $\alpha$ ) Maintains Survival of Committed Erythroid Cells in Fetal Liver Erythropoiesis through the STAT5 Pathway
}

\author{
Weiqian Chen, ${ }^{\star \dagger}$ Pengyu Gu, ${ }^{*}$ Xuan Jiang, ${ }^{*}$ \\ Hai-Bin Ruan, ${ }^{*}$ Chaojun $\mathrm{Li}^{,{ }^{\dagger}}$ and Xiang Gao* \\ From Key Laboratory of Model Animal for Disease Study of \\ Ministry of Education, Model Animal Research Center, and the \\ Medical School, ${ }^{\dagger}$ Nanjing University, Nanjing, China
}

Suppression of programmed cell death is critical for the final maturation of red blood cells and depends largely on the anti-apoptotic effects of EpoR-STAT5Bcl- $x_{\mathrm{L}}$ signaling. As the major eukaryotic serine/threonine phosphatase, protein phosphatase 2A (PP2A) regulates multiple cellular processes, including apoptosis. However, whether PP2A plays a role in preventing erythroid cells from undergoing apoptosis remains to be elucidated. We conditionally inactivated the catalytic subunit $\alpha$ of PP2A (PP2Ac $\alpha$ ), which is the predominant form of PP2Ac, during early embryonic hematopoiesis. Loss of PP2Ac $\alpha$ in hematopoietic cells perturbed definitive erythropoiesis characterized by fetal liver atrophy, reduced $\mathrm{Ter}^{119}{ }^{+}$cell number, abnormal expression patterns of molecular markers, less colony formation, and a reduction in definitive globin expression. Levels of erythropoiesis-promoting cytokines and initial seeding with hematopoietic progenitors remained unchanged in PP2Ac $\alpha^{\text {TKO }}$ fetal livers. We noted impaired expansion of the fetal erythroid compartment, which was associated with increased apoptosis of committed erythroid cells. Mechanistically, PP2Ac $\alpha$ depletion markedly reduced $\mathrm{Tyr}^{694}$ phosphorylation of STAT5 and expression of Bcl- $x_{\mathrm{L}}$. Unexpectedly, PP2Ac $\alpha$-deficient embryos did not manifest any early embryonic vascular defects. Collectively, these data provide direct loss-of-function evidence demonstrating the importance of PP2Ac $\alpha$ for the survival of committed erythroid cells during fetal liver erythropoiesis. (Am J Pathol 2011, 178:2333-2343; DOI: 10.1016/j.ajpath.2011.01.041)

The production of red blood cells (RBCs) is normally maintained at a constant level by well-tuned regulation of erythropoiesis. During terminal maturation, mammalian erythroblasts accumulate hemoglobin, assemble the $\mathrm{RBC}$ cytoskeleton, extrude their nuclei, and give rise to RBCs. ${ }^{1}$ Suppression of programmed cell death is considered to be critical for the final maturation of RBCs and depends strongly on anti-apoptotic effect of erythropoietin (EPO) stimulation and the intracellular EpoR-STAT5$\mathrm{BCl}-\mathrm{x}_{\mathrm{L}}$ signaling axis. ${ }^{2} \mathrm{EPO}^{-1-}$ and $\mathrm{EpoR}^{-1-}$ mice die at embryonic day (E) 13.5 owing to a failure in definitive erythropoiesis. ${ }^{3}$ STAT5 $^{\triangle N}$ mice are embryonic anemic due to decreased survival of RBC progenitors. ${ }^{4,5} \mathrm{BCl}-x$ is a member of the Bclll gene family, the members of which share homology in four conserved regions $(\mathrm{BH} 1-4$ domains), which control their dimerization and function. The expression of $\mathrm{Bcl}-\mathrm{x}$ is increased in terminally differentiated erythroblasts, ${ }^{6}$ during which stage it positively regulates the survival of these cells. ${ }^{7}$ Indeed, $\mathrm{Bcl}-\mathrm{x}$-deficient mice are embryonic lethal owing to massive apoptosis of immature erythroid cells in the fetal liver. ${ }^{8}$ Factors that regulate the survival of maturing erythroblasts are also relevant to clinical anemia induced by chemotherapy and chronic diseases, such as renal disorders, myeloma, and myelodysplasic syndromes. ${ }^{9-11}$

In eukaryotic cells, at least $30 \%$ of proteins can be modulated by reversible phosphorylation. Controlled protein phosphorylation, mediated by protein kinases and phosphatases, regulates multiple cellular processes, including apoptosis. ${ }^{12,13}$ Deregulation of apoptosis can lead to many human diseases, including cancer, Alzheimer's disease, cardiac dysfunction, and inflammation, ${ }^{14,15}$ most of which have been reported to involve deregulation of protein phosphatase 2A (PP2A), ${ }^{13,16,17}$ the major eukaryotic serine/threonine phosphatase. However, whether PP2A also plays a role in preventing erythroid cells from undergoing programmed cell death is

Supported in part by the National Science Foundation (30825024) and the Ministry of Science and Technology of China (2006BAl23B00, 2005CB522501, and 2006CB943500).

Accepted for publication January 28, 2011.

Supplemental material for this article can be found at http://ajp. amjpathol.org or at doi: 10.1016/j.ajpath.2011.01.041.

Address reprint requests to Xiang Gao, Ph.D., Model Animal Research Center, 12 Xuefu Rd., Nanjing 210061, China. E-mail: gaoxiang@nju.edu.cn. 
still largely unknown. The only previously reported function of PP2A in erythropoiesis is associated with activation of $\mathrm{K}-\mathrm{Cl}$ cotransport. ${ }^{18}$

Heterotrimeric PP2A is composed of a scaffold subunit (A subunit), a catalytic subunit (PP2Ac), and a regulatory subunit (B subunit). ${ }^{19}$ The scaffold subunit is flexible and structurally links PP2Ac with various regulatory subunits to form different holoenzymes. Molecular cloning has revealed the existence of two mammalian PP2Ac isoforms: PP2Ac $\alpha$ (encoded by the Ppp2ca gene) and PP2Ac $\beta$ (encoded by the Ppp2cb gene). These two isoforms share $97 \%$ amino acid identity, and seven of the eight residues that differ between them are located within the first 30 amino acids (encoded by exon I). ${ }^{13,20}$ Both PP2Ac isoforms are ubiquitously expressed, and PP2Ac $\alpha$ transcripts are generally 10 -fold more abundant than are $\mathrm{PP} 2 \mathrm{Ac} \beta$ transcripts owing to transcriptional regulation. ${ }^{21,22}$ However, detailed interpretation of the specific contribution of these two isoforms has long been hampered owing to the lack of reliable antibodies or specific chemical inhibitors that can distinguish between them. We sought to address a role for PP2Ac $\alpha$ in erythropoiesis using a genetic approach.

Conventional deletion of the Ppp2ca allele in mice results in embryonic lethality after E6 due to absent mesoderm formation, ${ }^{23}$ making it impossible to determine the functional importance of Ppp2ca in embryonic erythropoiesis. Herein, we conditionally inactivated the Ppp2ca allele during early embryonic hematopoiesis by using Tie2Cre transgenic mice, which are ideal models to induce early gene recombination in hematopoietic and endothelial cells. ${ }^{24}$ We discovered that loss of the Ppp2ca allele perturbed fetal liver erythropoiesis. PP2Ac $\alpha$ was not required to establish the fetal liver hematopoietic stem and progenitor cells (HSCs/Ps) pool; however, it enhanced the cell survival function of EPO. It acted, at least in part, by promoting the STAT5-BCl- $\mathrm{X}_{\mathrm{L}}$ axis and, thereby, inhibiting apoptosis of committed erythroid cells.

\section{Materials and Methods}

\section{Mice and Genotyping}

Mice carrying the conditional Ppp2ca allele (Ppp2ca $\left.{ }^{f / f t}\right)$ were bred with Tie2Cre mice, ${ }^{25}$ which were purchased from The Jackson Laboratory (Bar Harbor, ME). To visualize cells with recombined alleles, mice bearing the Tie2Cre transgene were crossed with ROSA26 reporter mice. ${ }^{26}$ All mice used in this study were of a mixed 129/B6 background. Mice were maintained in an Association for Assessment and Accreditation of Laboratory Animal Care International-credited specific pathogenfree animal facility, and animal welfare and experimental procedures were approved by the Animal Care and Use Committee of the Model Animal Research Center, the host for the National Resource Center for Mutant Mice in China, Nanjing University. Genotyping was performed by PCR analyses of genomic DNA isolated from mouse tails or yolk sacs. Genotyping primer sets and PCR reaction
Table 1. Genotyping Primers

\begin{tabular}{|c|c|}
\hline Primer name & Primer sequence \\
\hline First loxP & $\begin{array}{l}\text { F: 5'-AAGTTACTGAGTGCAGTGTGCCTTG-3, } \\
\text { R: 5'-TTATACCCTTCCTCATTCGCTCTGC-3' }\end{array}$ \\
\hline Second loxP & $\begin{array}{l}\text { F: 5'-TAGCCCATGCCTTTAATCTCAGAGC-3' } \\
\text { R: 5'-CACTCGTCGTAGAACCCATAAACC-3' }\end{array}$ \\
\hline Cre & $\begin{array}{l}\text { F: 5'-GCCTGCATTACCGGTCGATGC-3' } \\
\text { R: } 5^{\prime} \text {-CAGGGTGTTATAAGCAATCCC-3' }\end{array}$ \\
\hline DNA-EXdel & $\begin{array}{l}\text { F: 5'-AACCCACCCTTGAGAAACAGC-3' } \\
\text { R: 5'-TACCCTTCCTCATTCGCTCTG-3' }\end{array}$ \\
\hline RNA-EXdel & $\begin{array}{l}\text { F: 5'-ATTACCTGTTTATGGGAGACTATGT-3' } \\
\text { R: 5'-AAGTGGTCACGGCTGTTGATG-3' }\end{array}$ \\
\hline
\end{tabular}

$F$, forward; $R$, reverse.

programs are listed in Table 1 and in Supplemental Table S1 (available at $h t t p: / / a j p . a m j p a t h o l . o r g)$, respectively.

\section{Timed Mating and Tissue Harvesting}

Female Ppp2ca ${ }^{f l f l}$ mice were mated with male Tie2Cre ${ }^{+} /$ Ppp2ca ${ }^{f / /}+$ mice for embryo collection. Fetal livers were dissociated mechanically by pipetting for fluorescenceactivated cell sorting (FACS) analyses. Single-cell suspensions were prepared by drawing medium and cells up and down through a 1-mL syringe and 27-gauge needle.

\section{Cell Cultures and EPO Stimulation}

Fetal liver cells from E12.5 embryos were cultured in Iscove's modified Dulbecco's medium with $2 \%$ fetal bovine serum. Cells were maintained at $37^{\circ} \mathrm{C}$ and $5 \% \mathrm{CO}_{2}$ in the presence or absence of $10 \mathrm{U} / \mathrm{mL}$ recombinant human EPO. For the annexin $\mathrm{V}$ binding assay, stimulation lasted 18 hours. ${ }^{27}$ For the Western blot assay, stimulation lasted 15 minutes.

\section{Immunostaining, Flow Cytometric Analyses, and Cell Sorting}

Freshly isolated fetal liver cells were stained with different combinations of Ter119-PE, CD45-FITC, Gr-1-FITC, CD41-FITC, c-Kit-APC, CD71-biotin, and streptavidinPECy5. Megakaryocyte progenitors and megakaryocytes were sorted as $\mathrm{Lin}^{-} \mathrm{C}-\mathrm{Kit}^{+} \mathrm{CD} 41^{+}$and $\mathrm{Lin}^{-} \mathrm{C}-\mathrm{Kit}^{-} \mathrm{CD} 41^{+}$ cells, respectively. ${ }^{28}$ For analysis of $\mathrm{Lin}^{-} \mathrm{Sca}-1^{+} \mathrm{C}-\mathrm{Kit}^{+}$ (LSK) cells, fetal liver cells were stained with c-Kit-APC, Sca-1-FITC, and a lineage marker cocktail containing CD3-PE, CD5-PE, B220-PE, Gr-1-PE, and Ter119-PE. Apoptotic cells were verified using annexin V-FITC and Ter119-PE double staining. Endothelial cells were selected as $\mathrm{CD} 31^{+} \mathrm{CD} 45^{-}{ }^{29}$ Stained cells were analyzed using a FACSCalibur flow cytometer equipped with CellQuest software or were sorted using LSR II and four-laser FACSAria II sorters (all from Becton Dickinson, San Jose, CA). Sorted cells were collected in buffer containing RNase inhibitor and were stored at $-70^{\circ} \mathrm{C}$. The calculated absolute fetal liver cell numbers and the percentages of Ter $119^{+}, \mathrm{CD}_{4} 5^{+}, \mathrm{Gr}-1^{+}, \mathrm{Lin}^{-} \mathrm{C}-\mathrm{Kit}^{+} \mathrm{CD} 41^{+}$, $\mathrm{Lin}^{-} \mathrm{C}-\mathrm{Kit}^{-} \mathrm{CD} 41^{+}, \mathrm{LSK}$, and CD $31^{+} \mathrm{CD} 45^{-}$cells allowed for the determination of absolute cell numbers of these particular cell lineages in whole fetal liver samples. 
Table 2. Primers Used for Quantitative PCR

\begin{tabular}{|c|c|c|}
\hline Gene & Forward primer & Reverse primer \\
\hline Ppp2cb & 5'-GAGGGTACTACTCTGTGGAGAC-3' & 5'-CCGGCTTTCGTGATTTCCT-3' \\
\hline$\beta^{\text {maj/min }}$ & $5^{\prime}-$ ATGGCCTGAATCACTTGGAC-3' & 5'-ACGATCATATTGCCCAGGAG-3' \\
\hline$\beta H 1$ & $5^{\prime}-$ TCCTTGGGCTTGGGGGTTA $-3^{\prime}$ & $5^{\prime}-$ TGTGGGACAGAGCATTGGC $-3^{\prime}$ \\
\hline$\epsilon y$ & 5'-TGGCCTGTGGAGTAAGGTCAA-3' & 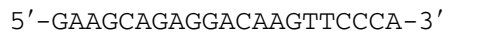 \\
\hline$E P O$ & 5'-CAGGCCCTGCTAGCCAATT-3' & $5^{\prime}$-ACGTAGACCACTGATGGCTTTGT-3' \\
\hline SCF & 5'-CCCTGAAGACTCGGGCCTA- $3^{\prime}$ & $5^{\prime}$-CAATTACAAGCGAAATGAGAGCC $-3^{\prime}$ \\
\hline$B c / x$ & 5'-ACTGTGCGTGGAAAGCGTAGA-3' & 5'-TGCTGCATTGTTCCCGTAGAG-3' \\
\hline Pim1 & 5' -TTCTGGACTGGTTCGAGAGG-3' & $5^{\prime}$-GCTCCTCGTTCGGTGATAAA-3' \\
\hline Cis1 & $5^{\prime}$-CCACTGGCTTTGTCAAGAAGG-3' & $5^{\prime}$-AGGCCACATAGTGCTGCACAA-3' \\
\hline Socs3 & 5'-CCGCTTCGACTGTGTACTCAAG-3' & $5^{\prime}$-TCTTCTCGCCCCCAGAATAGAT-3' \\
\hline Osm & $5^{\prime}-$ AACTGAGCAAGCCTCACTTCC-3' & 5'-ATGCCGAGGATATTGTGCCG-3' \\
\hline GAPDH & $5^{\prime}-$ TGCCCAGAACATCATCCCT-3' & 5'-GGTCCTCAGTGTAGCCCAAG-3' \\
\hline
\end{tabular}

\section{In Vitro Colony Formation Assays}

Fetal liver cells from E12.5 embryos were harvested in Iscove's modified Dulbecco's medium with $2 \%$ fetal bovine serum. For the erythroid colony-forming unit (CFU-E) assay, $2 \times 10^{4}$ cells were plated in $1 \mathrm{~mL}$ of methylcellulose medium supplemented with EPO (MethoCult M3334; STEMCELL Technologies Inc., Vancouver, BC, Canada) and were cultured for 2 days. For the erythroid blastforming unit (BFU-E) assays, $1 \times 10^{5}$ cells were plated in $1 \mathrm{~mL}$ of methylcellulose medium and were cultured for 7 days. Erythroid colonies were stained for hemoglobin using benzidine. CFU-E contained 8 to 32 benzidinepositive cells and BFU-E contained 3 or more clusters of CFU-E. The reported values are mean \pm SEM as determined for three or four embryos from each genotype.

\section{Phosphatase Activity Determination}

Tissue protein was extracted in a phosphatase extraction buffer containing $20 \mathrm{mmol} / \mathrm{L}$ imidazole- $\mathrm{HCl}, 2 \mathrm{mmol} / \mathrm{L}$ EDTA, 2 mmol/L EGTA (pH 7.0), 1 mmol/L benzamidine, $1 \mathrm{mmol} / \mathrm{L}$ phenylmethylsulfonyl fluoride, and protein inhibitor cocktails. Phosphatase activity was quantified using a malachite green-based PP2A Assay Kit (Upstate Biotechnology, Waltham, MA). Briefly, total proteins were immunoprecipitated with anti-PP2Ac, and PP2Ac-bound beads were incubated with synthetic phosphopeptide for the dephosphorylation reaction. The reaction supernatant was then mixed with malachite green reagent for color development. Changes in absorbance were measured at $650 \mathrm{~nm}$.

\section{RNA Isolation, Reverse Transcription, and Quantitative PCR}

RNA from sorted cells was extracted using RNAspin Mini Kit (GE Healthcare Bio-Sciences Corp, Piscataway, NJ), whereas RNA from fetal livers was isolated using RNAiso (Takara Bio Inc., Shiga, Japan). Reverse transcription was performed using a first-strand cDNA synthesis kit. Quantitative PCR-based measurements of RNA abundance were performed using SYBR green reagents in an ABI 7300 sequence detector (Applied Biosystems, Foster City, CA). Amplification of the GAPDH gene served as an input control of cDNA templates. Primers used in this study are listed in Table 2. Efficiency of amplification for all primers was validated by determining the slope of CT versus dilution series.

\section{Western Blotting}

Tissue or cell proteins were extracted using $1 \%$ Nonidet P-40 (Caledon Laboratories Ltd., Georgetown, ON, Canada), $20 \mathrm{mmol} / \mathrm{L}$ Tris $\cdot \mathrm{HCl}$ ( $\mathrm{pH}$ 8.0), $5 \mathrm{mmol} / \mathrm{L}$ EDTA, 0.5 $\mathrm{mmol} / \mathrm{L}$ EGTA, $150 \mathrm{mmol} / \mathrm{L} \mathrm{NaCl}, 10 \%$ glycerol, 20 $\mathrm{mmol} / \mathrm{L} \quad \beta$-glycerophosphate, protein inhibitors, and phosphatase inhibitors. Primary antibodies used in this study included anti-PP2Ac (Upstate Biotechnology), antiPP2A-A $\alpha / \beta$ (Santa Cruz Biotechnology, Santa Cruz, CA), anti-pTyr694-STAT5 (Cell Signaling Technology Inc., Beverly, MA), anti-STAT5 (Cell Signaling Technology Inc.), and anti-Bcl-X $\mathrm{X}_{\mathrm{L}}$ (eBioscience Inc., San Diego, CA).

\section{Whole-Mount LacZ Staining}

Embryos were fixed on ice in fixation buffer containing $0.2 \%$ glutaraldehyde, $5 \mathrm{mmol} / \mathrm{L}$ EGTA (pH 8.0), and $2 \mathrm{mmol} / \mathrm{L}$ $\mathrm{MgCl}_{2}$ in PBS. Samples were washed with rinse buffer containing $0.01 \%$ sodium deoxycholate, $0.02 \%$ Nonidet P-40, 5 $\mathrm{mmol} / \mathrm{L}$ EGTA (pH 8.0), and $2 \mathrm{mmol} / \mathrm{L} \mathrm{MgCl}_{2}$ in PBS. Samples were then stained with lacZ staining buffer containing 1 $\mathrm{mg} / \mathrm{mL}$ 5-bromo-4-chloro-3-indolyl- $\beta$-D-galactopyranoside (X-Gal), $10 \mathrm{mmol} / \mathrm{L} \mathrm{K} \mathrm{K}_{3} \mathrm{Fe}(\mathrm{CN})_{6}, 10 \mathrm{mmol} / \mathrm{L} \mathrm{K}{ }_{4} \mathrm{Fe}(\mathrm{CN})_{6}$, and $20 \mathrm{mmol} / \mathrm{L}$ Tris $\cdot \mathrm{HCl}(\mathrm{pH}$ 7.3) in rinse buffer. Stained tissues were paraffin embedded, sectioned, and counterstained with nuclear fast red.

\section{Statistical Analysis}

Data were analyzed using two-tailed $t$-tests and are presented as mean \pm SEM.

\section{Results}

\section{In Vivo Inactivation of PP2Ac $\alpha$ in Tie2-Expressing Cell Lineages (PP2Ac ${ }^{T K O}$ Mice)}

For this study, we generated the Ppp2ca ${ }^{f / f l}$ mice, in which two loxP sites were introduced into the $3^{\prime}$ and $5^{\prime}$ ends of 
A

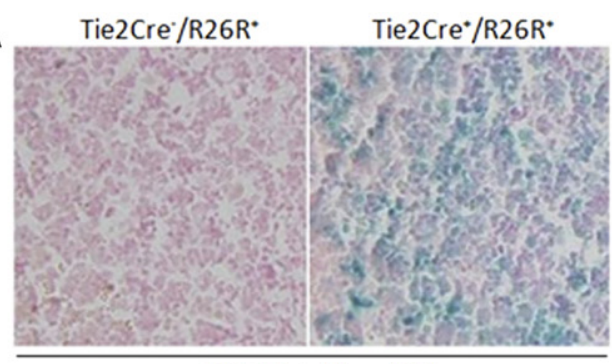

E12.5 fetal liver (FL)

B
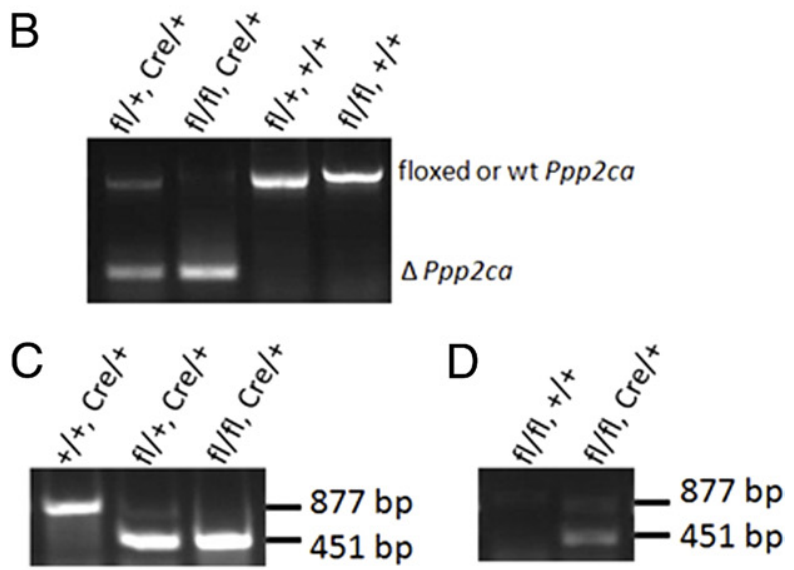

E
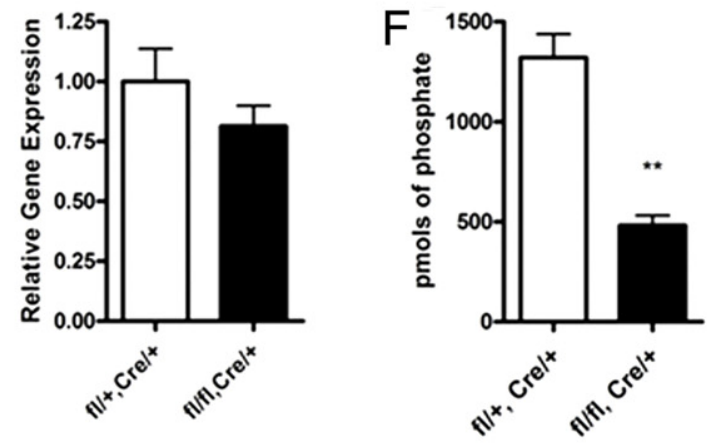

G

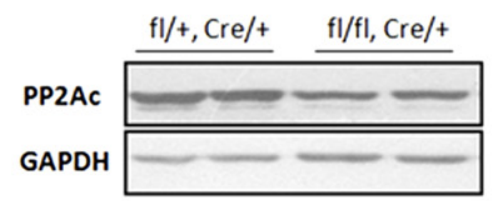

$\mathrm{H}$

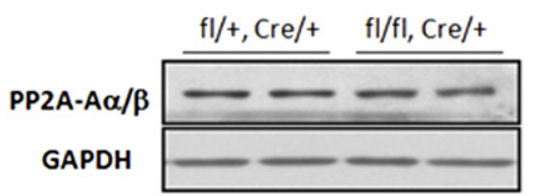

Figure 1. Deletion efficiency of PP2Ac $\alpha$ in E12.5 PP2Ac $\alpha^{\mathrm{TKO}}$ fetal livers. A: LacZ-stained sections of Tie $2^{+}$Cre fetal liver carrying a $R O S A 26$ allele show the relatively sporadic distribution of blue cells. B: Deletion efficiency of the $P p p 2 c a$ allele was analyzed using genomic DNA from the fetal liver. A 339-bp fragment should appear with "DNA-EXdel" primers if Cre-mediated recombination occurs. C: RT-PCR was performed to verify PP2Ac $\alpha$ mRNA. The cDNA containing exons 2 to 7 was amplified with "RNA-EXdel" primers. The 877 -bp and 451-bp products reflect wild-type and mutant PP2Ac $\alpha$, respectively. D: RT-PCR was performed to verify PP2Ac $\alpha$ mRNA in sorted HSCs in fetal livers. E: Quantitative PCR assay for PP2Ac $\beta$ mRNA in E12.5 fetal livers ( $n=6$; average \pm SEM). F: PP2A phosphate activity in the fetal liver was tested $\left(n=5 ;{ }^{*} P<0.05\right.$; average \pm SEM). G: Total PP2Ac protein level was determined using an antibody detecting PP2Ac $\alpha$ and PP $2 \mathrm{Ac} \beta$. H: Expression of the A subunit of PP2A was determined with an antibody specific for PP2A-A $\alpha$ and PP2A-A $\beta$. the region spanning exons 3 to 5 of the Ppp2ca gene (data not shown). To conditionally inactivate the Ppp2ca allele during embryonic hematopoiesis, we used two mouse lines, Ppp2ca ${ }^{f / f l}$ mice and Tie2Cre mice, in which the Cre transgene is directed under the receptor tyrosine kinase Tek promoter/enhancer. Because Tie2Cre mice also exhibit Cre expression in the female germline, the Cre allele was maintained only in male mice in this study. To generate PP2Ac $\alpha^{\text {TKO }}$ (Tie2Cre $/$ Ppp2ca ${ }^{t / / f}$ ) mice, we first set up mating between male Tie2Cre ${ }^{+}$and female Ppp2ca ${ }^{f /+}$ mice. Male Tie2Cre $/ \mathrm{Ppp} 2 \mathrm{ca}^{\mathrm{fl} /+}$ mice were subsequently mated with female Ppp2call/fl mice to generate PP2Ac $\alpha^{\text {TKO }}$ mice (see Supplemental Figure S1A at http://ajp.amjpathol.org). PCR analyses of genomic DNA from mouse tails were performed to verify the expected genotypes (see Supplemental Figure S1, B and C, at http://ajp.amjpathol.org).

\section{PP2Ac $\alpha$ Recombination Efficiency in the Fetal Liver}

In addition to endothelial cells, HSCs/Ps in mouse embryos have also been reported to express Tie2. ${ }^{30-32}$ On initiation of the hematopoietic program, Tie2 regulatory elements are transiently active in hematopoietic progenitors. To determine the extent of Cre expression in the fetal liver, we bred Tie2Cre mice with ROSA26-LacZ reporter mice. The relatively sporadic blue staining in fetal livers of mice carrying the Cre and the floxed Ppp2ca alleles indicated the distribution pattern of hematopoietic cells having undergone Tie2Cre-mediated gene recombination (Figure 1A). To verify the excision efficiency of the Ppp2ca allele, we harvested genomic DNA, cDNA, and protein from E12.5 fetal livers. Figure 1B shows data confirming that recombination occurred in the floxed Ppp2ca genomic locus in Tie2Cre $/$ Ppp2cal/ ${ }^{f /+}$ and Tie2Cre $/ \mathrm{Ppp} \mathrm{ca}^{\mathrm{fl} / \mathrm{fl}}$ embryos. To confirm that deletion of the targeted exons indeed altered Ppp2ca expression, we measured mRNA and protein levels of PP2Ac $\alpha$ and $\mathrm{PP} 2 \mathrm{Ac} \beta$ in fetal livers. RT-PCR analyses showed that transcription of the Ppp2ca gene was truncated in total fetal liver cells (Figure 1C) and sorted HSCs (LSK) of PP2Ac $\alpha^{\text {TKO }}$ embryos (Figure 1D), although intact transcripts were still observed. Transcription of Ppp2cb was not altered by excision of the Ppp2ca allele (Figure 1E). Owing to the high sequence similarity between PP2Ac $\alpha$ and PP2Ac $\beta$, we did not have a reliable antibody to distinguish between these two isoforms. However, total quantity of catalytic subunit was still substantially reduced in PP2Ac $\alpha^{\text {TKO }}$ fetal livers (Figure 1G). PP2A phosphatase activity in PP2Ac $\alpha^{\text {TKO }}$ samples was approximately $36.4 \%$ of the activity observed in $\mathrm{Tie}^{-} \mathrm{Cre}^{+} /$ Ppp2cal/ fetal livers (Figure 1F). Expression of the scaffolding subunit of PP2A remained unchanged despite loss of the Ppp2ca allele (Figure $1 \mathrm{H}$ ). PP2Ac protein quantity and PP2A phosphatase activity were similar between Tie2Cre ${ }^{+} / \mathrm{Ppp}_{\mathrm{Ca}}{ }^{+/+}$and Tie2Cre $/$Ppp2ca ${ }^{\text {fl/ }}$ fetal livers (see Supplemental Figure S2 at http://ajp.amjpathol.org). In subsequent experiments, we used Tie2Cre ${ }^{+} / \mathrm{Ppp} \mathrm{ca}^{\mathrm{fl} /+}$ mice as controls (CTRs). 


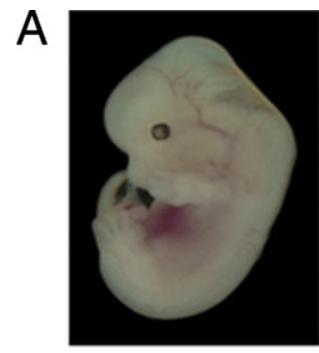

CTR

D

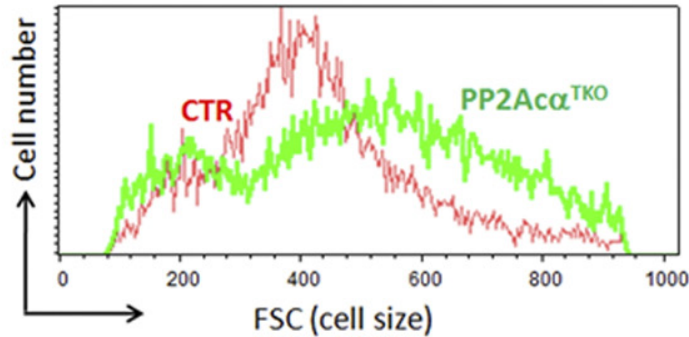

B

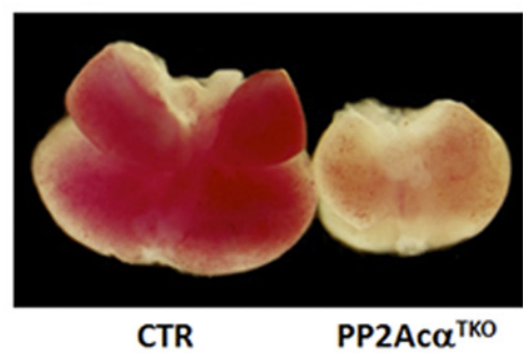

$\mathrm{E}$

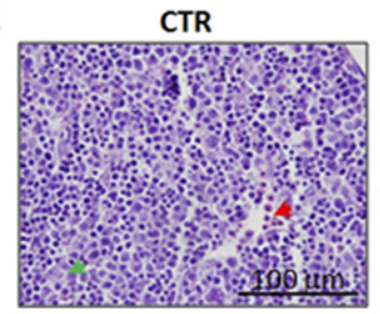

C

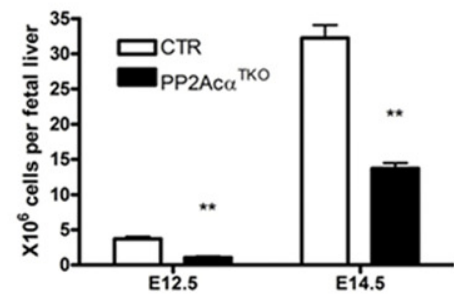

PP2Ac $\alpha^{\text {TKO }}$

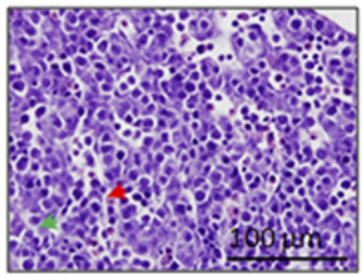

Figure 2. Impaired hematopoiesis in PP2Ac $\alpha^{\text {TKO }}$ embryos. Gross morphologic features of E12.5 embryos (A) and isolated E12.5 fetal livers (B). C: Cell number per fetal liver was calculated ( $n=5$ to $8 ;{ }^{* *} P<0.05$; average \pm SEM). D: Cell size of CTR and PP2Ac $\alpha^{\text {TKO }}$ fetal liver cells derived from E12.5 embryos was determined by forward scatter (FSC) measurement by FACS. E: H\&E staining of E12.5 fetal liver sections showing hepatocytes (green arrows) and hematopoietic cells (red arrows)

\section{PP2Ack ${ }^{\text {TKO }}$ Embryos Manifest Fetal Anemia}

PP2Ac $\alpha^{\text {TKO }}$ embryos were pale, indicating defective hematopoiesis (Figure 2A). The CTR fetal liver showed a bright red appearance compared with the pale fetal liver of PP2Ac $\alpha^{\text {TKO }}$ embryos (Figure 2B). The total cellularity of $\mathrm{PP} 2 \mathrm{Ac} \alpha^{\mathrm{TKO}}$ fetal liver was dramatically reduced at E12.5 and E14.5 (Figure 2C). PP2Ac $\alpha^{\text {TKO }}$ fetal liver cells were also larger (macrocytic) than CTR cells (Figure 2D). As determined by histologic analyses, CTR livers contained numerous hematopoietic elements. In contrast, PP2Ac $\alpha^{\text {TKO }}$ fetal livers consisted primarily of hepatic cells and, infrequently, hematopoietic progenitors or nucleated primitive RBCs (Figure 2E).

\section{Erythropoiesis is Impaired in PP2Ac $\alpha^{T K O}$ \\ Fetal Livers}

To confirm and clarify hematopoietic defects in PP2Ac $\alpha$ deficient embryos, we analyzed the expression of several hematopoietic lineage markers in E14.5 fetal livers, such as Ter $119^{+}$for erythrocytes, CD45 ${ }^{+}$for leukocytes, ${ }^{33} \mathrm{Gr}-1^{+}$for granulocytes, $\mathrm{Lin}^{-} \mathrm{C}-\mathrm{Kit}^{+} \mathrm{CD} 41^{+}$for megakaryocyte progenitors, and $\mathrm{Lin}^{-} \mathrm{C}-\mathrm{Kit}^{-} \mathrm{CD} 41^{+}$for megakaryocytes ${ }^{28}$ (Figure 3A). The absolute number of $\mathrm{Ter}^{119^{+}}$cells in PP2Ac $\alpha^{\text {TKO }}$ fetal liver was dramatically reduced to approximately $11.8 \%$ of that in CTRs (CTR versus PP2AC $\alpha$ TKO: $3.39 \times 10^{7} \pm 5.79 \times 10^{6}$ versus $4.02 \times 10^{6} \pm 1.86 \times 10^{6}$ cells per fetal liver), whereas no statistically significant differences were observed in the mean \pm SEM absolute num-

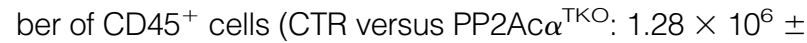
$1.51 \times 10^{5}$ versus $1.15 \times 10^{6} \pm 1.91 \times 10^{5}$ cells per fetal liver), $\mathrm{Gr}-1^{+}$cells (CTR versus PP2Ac $\alpha^{\text {TKO: }} 4.94 \times 10^{5} \pm$ $1.52 \times 10^{5}$ versus $3.90 \times 10^{5} \pm 1.34 \times 10^{5}$ cells per fetal liver), $\mathrm{Lin}^{-} \mathrm{C}-\mathrm{Kit}^{+} \mathrm{CD} 41^{+}$cells (CTR versus PP2Ac $\alpha^{\mathrm{TKO}}: 1.29 \times$
$10^{4} \pm 0.26 \times 10^{4}$ versus $1.49 \times 10^{4} \pm 0.34 \times 10^{4}$ cells per fetal liver), and $\mathrm{Lin}^{-} \mathrm{C}-\mathrm{Kit}^{-} \mathrm{CD} 41^{+}$cells (CTR versus PP2Ac $\alpha^{\text {TKO: }} 1.66 \times 10^{4} \pm 0.20 \times 10^{4}$ versus $1.75 \times 10^{4} \pm$ $0.78 \times 10^{4}$ cells per fetal liver). These findings suggest that the severe anemia observed in PP2Ac $\alpha^{\text {TKO }}$ embryos was mainly due to erythropoietic abnormalities, with no apparent impairment in other hematopoietic lineages. RT-PCR analyses of sorted Ter119 ${ }^{+}, \mathrm{CD}_{4} 5^{+}, \mathrm{Gr}-1^{+}$, and $\mathrm{CD} 41^{+}$cells revealed incomplete knockout of PP2Ac $\alpha$ in these particular hematopoietic lineages (Figure 3B). To explain the erythroid impairment phenotype, we hypothesize that considering their similar deletion efficiency, the maturation of erythroid and other hematopoietic lineages are differentially regulated.

Flow cytometry was performed to further verify the maturation stage of fetal liver erythroid cells. Expression of Ter119 marks committed erythropoietic precursors beyond the CFU-E stage, ${ }^{34,35}$ whereas C-Kit marks HSCs capable of long-term reconstitution. ${ }^{36}$ Proerythroblasts, characterized as the $\mathrm{C}^{-\mathrm{Kit}^{+}}$Ter $119^{-}$cell fraction, differ-

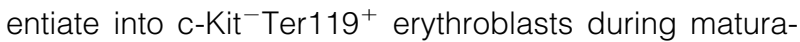
tion. However, this process was severely impaired in PP2Ac $\alpha^{\text {TKO }}$ embryos (Figure 3C). CD71 antibodies bind to the transferring receptor, which is highly expressed in proerythroblasts and early erythroblasts and decays in late erythroblasts and reticulocytes. Cells from CTR livers contained at least four distinct cell populations, defined by the following characteristic staining patterns: CD71 $1^{\text {med }}$ Ter $119^{\text {low }}$, CD71 $1^{\text {high }}$ Ter119low CD71 $^{\text {high }}$ Ter119 ${ }^{\text {high }}$, and $\mathrm{CD} 71^{\text {med }}$ Ter119high (Figure 3D, left, regions R1-R4, respectively). However, cell populations from PP2Ac $\alpha^{\text {TKO }}$ livers showed far fewer mature erythroblasts (Figure $3 \mathrm{D}$, right, regions R1-R4, respectively). Tie2Cre ${ }^{+} / \mathrm{Ppp}_{\mathrm{Ca}}{ }^{+/+}$and $\mathrm{Tie} \mathrm{Cre}^{+} /$ Ppp2ca ${ }^{f / /+}$ fetal livers had a similar, bright red appearance and c-Kit-Ter119 and CD71-Ter119 staining pat- 
A

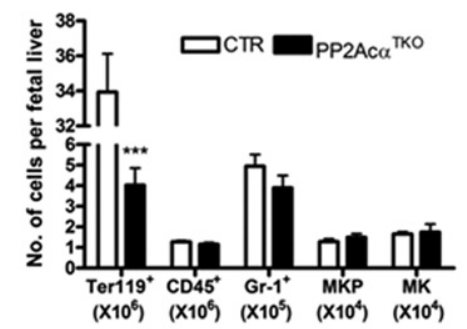

C

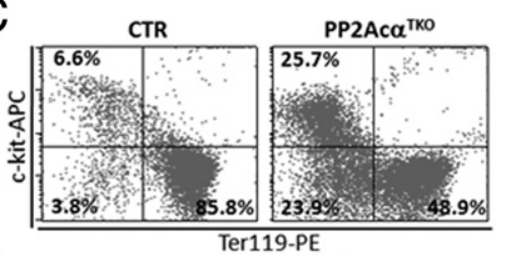

E

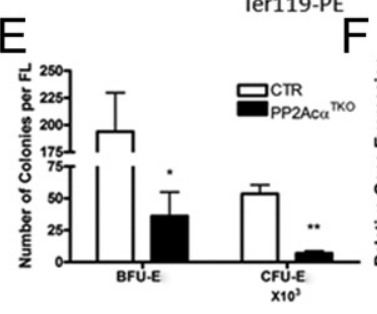

$F$
B

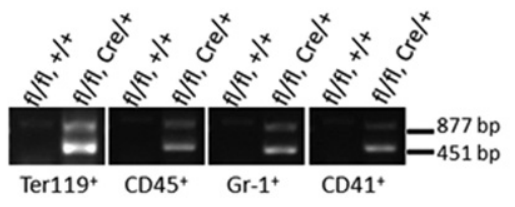

D

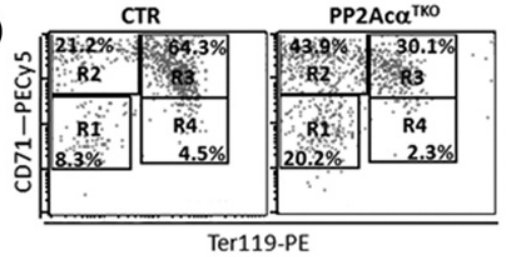

Ter119-PE

$G$
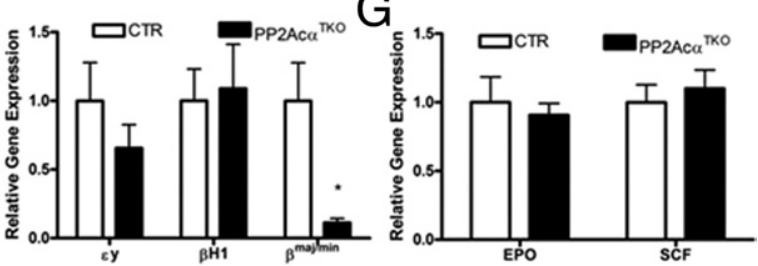

Figure 3. Perturbed erythropoiesis in PP $2 \mathrm{Ac} \alpha^{\mathrm{TKO}}$ fetal livers. Fetal livers from E14.5 embryos were harvested, and single-cell suspensions were prepared by passing livers through a $1-\mathrm{mL}$ pipette and filtering them through a $100-\mu \mathrm{m}$ cell strainer. Cell number was counted using a hemocytometer. Forty thousand cells were used for FACS analysis. A: The absolute numbers of Ter $119^{+}, \mathrm{CD} 45^{+}, \mathrm{Gr}-$

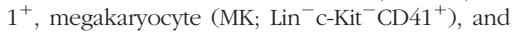
megakaryocyte progenitor (MKP; $\mathrm{Lin}^{-} \mathrm{C}^{-}$ $\left.\mathrm{Kit}^{+} \mathrm{CD} 41^{+}\right)$cells from CTR and PP2Ac $\alpha^{\mathrm{TKO}}$ fetal livers were calculated ( $n=4$ to 7 ; ${ }^{* * * * *} P<0.001$; mean \pm SEM). B: RT-PCR was performed to verify PP2Ac $\alpha$ mRNA in sorted Ter $119^{+}, \mathrm{CD} 45^{+}, \mathrm{Gr}-1^{+}$, and $\mathrm{CD} 41^{+}$fetal liver cells, as indicated. The cDNA containing exons 2 to 7 was amplified with "RNAEXdel" primers. FACS analysis was performed using anti-c-Kit and anti-Ter119(C) or anti-CD71 and anti-Ter119 (D) antibody combinations on E12.5 fetal liver cells. E: Absolute numbers of BFU-E and CFU-E per E12.5 fetal liver (FL) were calculated ( $n=3$ to $5 ;{ }^{*} P<0.05 ;{ }^{* *} P<0.01$; average \pm SEM). Quantitative RT-PCR analysis of $\varepsilon y-, \beta H 1-$, and $\beta^{\text {maj/min }}$-globin transcripts (F) and EPO and stem cell factor (SCF) $(\mathbf{G})$ transcripts in E12.5 fetal livers $\left(n=6 ;{ }^{*} P<0.05\right.$; average \pm SEM $)$.

terns, confirming that Tie2Cre ${ }^{+} / \mathrm{Ppp} 2 \mathrm{ca}^{\mathrm{fl} /+}$ fetal livers had normal embryonic erythropoiesis (see Supplemental Figure S3 at http://ajp.amjpathol.org).

The generation of mature RBCs involves the commitment of pluripotent HSCs that progress through the BFU-E and CFU-E stages and the proerythroblast and erythroblast stages and, finally, differentiate into enucleated erythrocytes. Fetal liver erythroid progenitors are dependent on EPO for survival and growth during the final 48 hours of differentiation. To better define the observed impairment in definitive erythropoietic differentiation in PP2Ac $\alpha^{\text {TKO }}$ embryos, we measured the ability of fetal liver cells to form CFU-E and the more immature BFU-E. These colony types reflect the presence of committed erythroid progenitors. As indicated in Figure 3E, the total numbers of BFU-E and CFU-E in PP2Ac $\alpha^{\text {TKO }}$ fetal livers were dramatically lower than those in CTR littermates (BFU-E: decreased by 81.4\%; CFU-E: decreased by $87.0 \%)$.

Further evidence for a defect in definitive erythropoiesis in PP2Ac $\alpha^{\text {TKO }}$ embryos was provided by quantitative RT-PCR analyses of globin gene expression. The transcriptional levels of $\varepsilon \mathrm{y}$ - and $\beta \mathrm{H} 1$-globin, which are expressed predominantly during primitive erythropoiesis, ${ }^{37}$ were similar in CTR and PP2AC $\alpha^{\text {TKO }}$ fetal livers. However, expression of $\beta^{\text {maj/min }}$-globin, which first occurs in fetal livers during definitive erythropoiesis, was significantly reduced in PP2Ac $\alpha^{\text {TKO }}$ embryos (Figure 3F). Collectively, these results indicate that primitive erythropoiesis proceeds normally in PP2Ac $\alpha^{\text {TKO }}$ embryos but that definitive erythropoiesis is severely dampened.

Several cytokines, including EPO and stem cell factor, are required for erythropoiesis. ${ }^{3,38-40}$ Quantitative RTPCR analyses revealed no statistically significant differences in the relative expression levels of EPO and stem cell factor between CTR and PP2Ac $\alpha^{\text {TKO }}$ samples, which precluded the possibility that PP2Ac $\alpha^{\mathrm{TKO}}$ embryos experience a deficiency in the production of erythropoiesispromoting cytokines (Figure 3G).

\section{Initial Seeding of the Fetal Liver with Hematopoietic Progenitors is Not Attenuated in PP2Ac $\alpha^{T K O}$ \\ Embryos}

Hematopoietic progenitor cells are primitive cells capable of producing mature cells of one or more lineages. Fetal hematopoiesis consists of the following steps: i) formation of short-lived progenitors and immature HSC precursors in the yolk sac and aorta-gonad-mesonephros region, ii) maturation of the precursor cells into functional HSCs, iii) migration of HSCs to the fetal liver at E10 for proliferation and differentiation, and iv) shifting of hematopoiesis to the bone marrow after birth for the remainder of life. ${ }^{41}$ To test for the possibility that the erythropoietic abnormality observed in PP2Ac $\alpha^{\text {TKO }}$ mice may result from an insufficient HSCs/Ps pool, the number of hematopoietic progenitors was calculated by sorting LSK cells to obtain a precise enumeration in individual fetal livers (Figure 4A). The statistical result revealed that the mean \pm SEM absolute quantity of LSK cells in $\mathrm{PP} 2 \mathrm{Ac} \alpha^{\mathrm{TKO}}$ fetal livers remained unchanged at E12.5

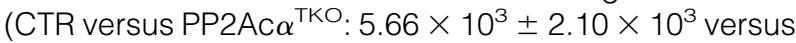
$4.58 \times 10^{3} \pm 2.74 \times 10^{3}$ cells per fetal liver) (Figure 4B). Mean \pm SEM absolute LSK cell quantity of E14.5 PP2Ac $\alpha^{\text {TKO }}$ embryos was even up-regulated, probably due to negative feedback modulation by ineffective erythropoiesis (CTR versus PP2Ac $\alpha^{\text {TKO: }} 1.89 \times 10^{4} \pm 5.36 \times$ $10^{3}$ versus $5.64 \times 10^{4} \pm 1.09 \times 10^{4}$ cells per fetal liver) (Figure 4B). These results indicate that the initial colonization of the fetal liver with HSCs/Ps is not attenuated by loss of the Ppp2ca allele. 
A

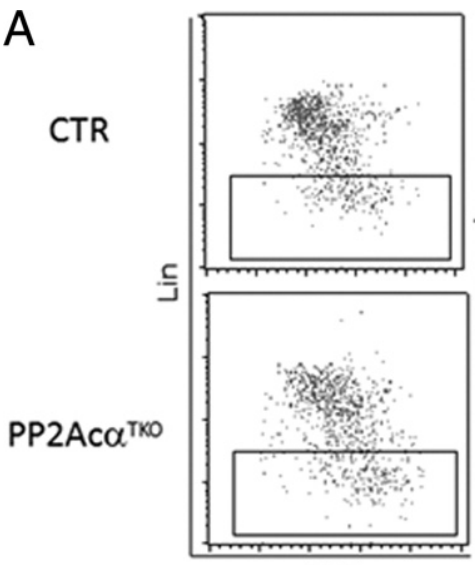

FSC

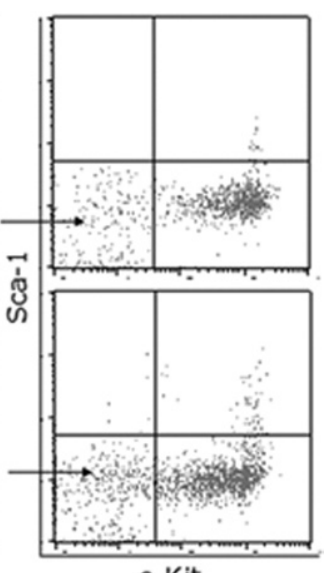

c-Kit
B

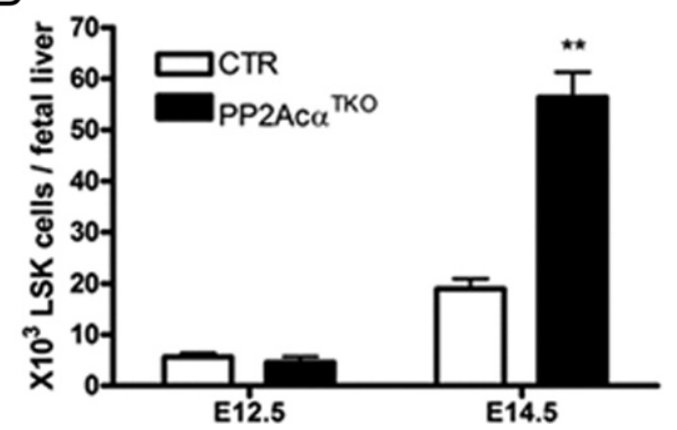

Figure 4. Analysis of LSK cell numbers in PP2Ac $\alpha^{\mathrm{TKO}}$ fetal livers. A: E12.5 fetal liver cells were sorted by representative lineage and sorting gates, as shown. B: Fetal liver cell numbers were counted using a hemocytometer and were analyzed using a flow cytometer. The cumulative counts of LSK cells obtained by FACS during the sorting procedure are shown $(n=5$ to 8 ; **a $P<$ 0.01 ; average \pm SEM).

\section{Increased Apoptosis in Cultured PP2Ac $\alpha$-Deficient Committed Erythroid Cells}

Fetal liver erythropoiesis is considered to be mechanistically similar to stress erythropoiesis in adult mice, as both processes are EPO responsive, which is essential for the survival of CFU-E. 2,42 We, therefore, examined the ability of EPO to prevent apoptosis of PP2Ac $\alpha^{\text {TKO }}$ erythroid cells. We cultured primary fetal liver cells and analyzed their sensitivity to apoptosis with or without EPO stimulation. After in vitro stimulation for 18 hours, cells were examined by FACS for the expression of Ter119 and annexin V. ${ }^{27}$ As illustrated in Figure 5A, significant fractions of apoptotic cells were evident in committed erythroid cell cultures of PP2Ac $\alpha^{\text {TKO }}$ fetal livers with or without EPO stimulation. This indicates that PP2Ac $\alpha^{\text {TKO }}$ erythroid cells are much more sensitive to apoptotic stimulation than are CTR cells.

\section{Defective STAT5-BCl- $x_{L}$ Signaling Is Responsible for the Reduced Survival of PP2Aca $\alpha^{T K O}$ Erythroid Cells}

Stress erythropoiesis in the spleen depends sharply on the EpoR-STAT5 signaling axis. We, therefore, investigated whether decreased survival of committed erythroid cells in PP2Ac $\alpha^{\mathrm{TKO}}$ embryos could result from misregulation of this signaling pathway, thus indicating cross talk between PP2A and STAT5 signaling. We evaluated transcripts of the five known STAT5 downstream genes, including $B C l-x,{ }^{5}$ proviral integration site-1 (Pim-1), ${ }^{43}$ Cis$1,{ }^{44}$ SOCS-3, ${ }^{45}$ and oncostatin-M (OncoM) ${ }^{46}$ in E12.5 fetal livers. Each of these genes has been reported to be included in fetal liver or stress erythropoiesis. The present results indicate that loss of the Ppp2ca allele impaired transcription of $B C l-x$, without overt influence on transcription of other genes (Figure $5 \mathrm{~B}$ ). $\mathrm{BCl}-\mathrm{x}$ is expressed predominantly in its long form, $\mathrm{Bcl}-\mathrm{x}_{\mathrm{L}},{ }^{47}$ which can function as an anti-apoptotic factor. Down-regulation of basal $\mathrm{Bcl}-\mathrm{x}_{\mathrm{L}}$ protein in PP2Ac $\alpha^{\mathrm{TKO}}$ fetal livers was confirmed by Western blot analysis (Figure 5C). Primary fetal liver cells were stimulated in vitro for 15 minutes with or without EPO. PP2Ac $\alpha^{\top K O}$ fetal liver cells exhibited an attenuated EPO response, as indicated by decreased tyrosine phosphorylation of STAT5 (pY694) and decreased Bcl- $\mathrm{X}_{\mathrm{L}}$ expression in basal and stimulated conditions (Figure 5D).

\section{Loss of the Ppp2ca Allele in Tie2 ${ }^{+}$Cells Results in Embryonic Lethality}

To determine the precise survival rate of PP2Ac $\alpha^{\text {TKO }}$ embryos, we examined embryos obtained from sched-

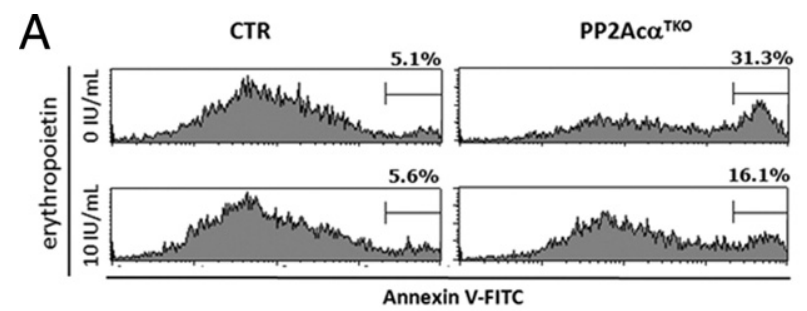

B

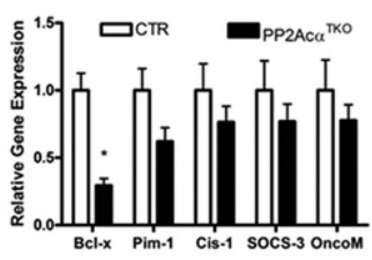

C

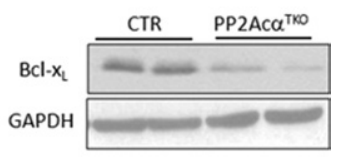

D

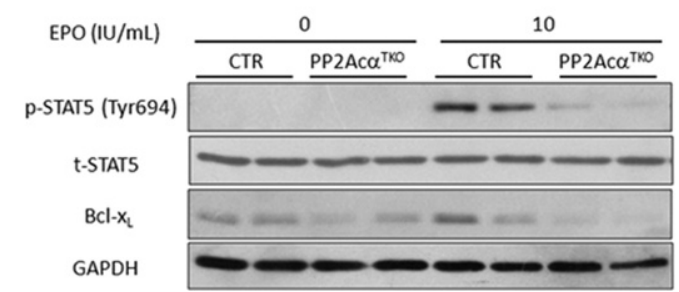

Figure 5. Increased apoptosis and impaired STAT5 signaling in PP2Ac $\alpha$ deficient fetal livers. A: Isolated E12.5 fetal liver cells were cultured in Iscove's modified Dulbecco's medium with $2 \%$ fetal bovine serum for 18 hours in the absence or presence of $10 \mathrm{U} / \mathrm{mL}$ recombinant human $\mathrm{EPO}$, and combined Annexin V-Ter119 staining was performed and quantified by FACS analysis. B: Quantitative PCR analyses of downstream STAT5 targets, including Bcl-x, Pim-1, cis-1, SOCS-3, and $\operatorname{OncoM}\left(n=6\right.$; ${ }^{*} P<0.05$; average \pm SEM). C: Western blot analysis of basal $\mathrm{Bcl}-\mathrm{x}_{\mathrm{L}}$ protein level in E12.5 fetal liver lysates. D: STAT5-Bcl- $\mathrm{X}_{\mathrm{L}}$ signaling after EPO stimulation. PP 2 Ac $\alpha^{\text {TKO }}$ and CTR fetal liver cells were treated with or without human EPO for 15 minutes and were immunoblotted with the indicated antibodies. 
uled matings (see Supplemental Table S2 at $h$ ttp://ajp. amjpathol.org). Mice with all four genotypes existed at the expected Mendelian ratio at E10.5. At E12.5, however, only 54 of the expected 69 PP2Ac $\alpha^{\text {TKO }}$ embryos were harvested, with 47 PP2Ac $\alpha^{\text {TKO }}$ embryos moribund and pale looking. At E14.5, the survival ratio of PP2Ac $\alpha^{\text {TKO }}$ embryos became even smaller. However, 8 of the expected 69 PP2Ac $\alpha^{\text {TKO }}$ pups survived until postnatal day 10 . Adult PP2Ac $\alpha^{\text {TKO }}$ mice did not show any visible abnormalities. They even exhibited a normal steady-state hematocrit (see Supplemental Figure S4 at http://ajp.amjpathol.org).

\section{$P P 2 A c \alpha^{T K O}$ Embryos Exhibit No Obvious Early Embryonic Vasculature Defects}

Because Tie2Cre mediates the excision of floxed DNA in hematopoietic and endothelial cells, we analyzed the vascular potential of blood vessels in PP2Ac $\alpha^{\mathrm{TKO}} \mathrm{em}$ bryos. Platelet endothelial cell adhesion molecule-1 and endomucin ${ }^{48}$ staining of whole-mount E10.5 embryos indicated that PP2Ac $\alpha^{T K O}$ embryos displayed no obvious abnormalities in early embryonic vasculature. Whole embryo views and close examination of the trunk and head regions confirmed these findings (Figure 6, A-E). LacZ whole-mount staining of embryos carrying a ROSA26 allele also revealed normal blood vessel development in PP2Ac $\alpha^{\text {TKO }}$ embryos at E10.5 (Figure 6F). Although the mean \pm SEM absolute number of nonhematopoietic cells $\left(\mathrm{CD} 45^{-}\right)$was dramatically reduced (CTR versus PP2Ac $\alpha^{\text {TKO: }} 2.17 \times 10^{6} \pm$ $0.66 \times 10^{6}$ versus $7.60 \times 10^{5} \pm 2.15 \times 10^{5}$ cells per fetal liver) (Figure 6G), the endothelial population $\left(\mathrm{CD} 31^{+} \mathrm{CD} 45^{-}\right)^{29}$ remained unchanged in E12.5

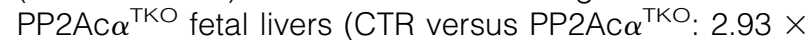
$10^{4} \pm 0.52 \times 10^{4}$ versus $3.15 \times 10^{4} \pm 0.91 \times 10^{4}$ cells per fetal liver) (Figure 6G). RT-PCR analyses of sorted $\mathrm{CD} 31^{+} \mathrm{CD} 45^{-}$cells revealed the complete absence of PP2Ac $\alpha$ mRNA, which precluded the possibility that the observed normal embryonic vasculature was due to inefficient knockout of PP2Ac $\alpha$ mRNA in endothelial cells of $\mathrm{PP} 2 \mathrm{Ac} \alpha^{\top \mathrm{TKO}}$ fetal liver (Figure $6 \mathrm{H}$ ).

\section{Discussion}

In this study, we delineate that sustained activity of PP2Ac $\alpha$ is crucial for fetal liver erythropoiesis. Considering that the colonization of PP2Ac $\alpha^{\text {TKO }}$ fetal livers with HSCs/Ps is not attenuated, we believe that the observed decrease in the survival of erythroid cells, itself the result of defective STAT5-BCl- $x_{L}$ signaling, is responsible for the impaired erythropoiesis phenotype in PP2Ac $\alpha^{\mathrm{TKO}}$ fetal livers. These results also indicate that signaling through PP2Ac $\alpha$ is not essential for early embryonic vasculature development.

\section{PP2Ac $\alpha$ Is Essential for the Survival of Committed Erythroid Cells}

Several lines of evidence suggest that PP2A activation is linked to apoptosis. PP2A plays pivotal dual roles in the induction of neutrophil apoptosis through dephosphorylation of p38 MAPK and its substrate, caspase $3 .{ }^{49}$ PP2A is a $\mathrm{Bcl}-2$ phosphatase and controls its major functional phosphorylation site (Ser70). ${ }^{50}$ PP2A has also been shown to colocalize with $\mathrm{Bcl}-2$ at the mitochondrial membrane and may be activated by ceramide to dephosphorylate $\mathrm{Bcl}-2 .{ }^{51}$ Activation of caspase- 3 causes cleavage of the $A$ subunit of PP2A, which, in turn, increases PP2A activity. ${ }^{52}$ Herein, we reported that conditional genetic deletion of PP2Ac $\alpha$ inhibited the survival of erythroid cells through regulation of $\mathrm{BCl}-\mathrm{x}_{\mathrm{L}}$ expression. $B C / x$ is expressed predominantly in its long form, $\mathrm{Bcl}-\mathrm{x}_{\mathrm{L}}$; however, other alternative splice variants, such as $\mathrm{Bcl}-\mathrm{x}_{S}$, have also been detected. ${ }^{53,54}$ Although $\mathrm{Bcl}-\mathrm{x}_{\mathrm{S}}$ can function as a pro-apoptotic factor in vitro, its expression has not been detected in erythroid cells. ${ }^{6} \mathrm{Bcl}-\mathrm{X}_{\mathrm{L}}$ is a direct target of STAT5, as STAT5 binds to its consensus element within intron 1 of the $B c l x$ gene and induces immediate early expression of Bcl- $x_{L}$ in HCD-57 cells. ${ }^{5}$

It is not clear why some PP2Ac $\alpha^{\text {TKO }}$ embryos showed such a severe anemia phenotype and a few PP2Ac $\alpha^{\text {TKO }}$ embryos survived to adulthood and demonstrated a normal steady-state hematocrit (see Supplemental Figure S4 at $h t t p: / / a j p . a m j p a t h o l . o r g)$. Possible explanations include i) the mixed 129/B6 genetic background; ii) the efficiency and/or timing of the recombination of the Ppp2ca floxed allele in the PP2Ac $\alpha^{\text {TKO }}$ population; and iii) the heterogeneity in the recombined cells' ability to compensate for deficient STAT5-BCl- $x_{L}$ signaling. The regulation of $B C l-x_{L}$ in erythroblasts is multifactorial and involves synergistic interaction of the EPO and GATA signaling pathways. ${ }^{55}$ In a manner similar to STAT5 ${ }^{\triangle \mathrm{N}}$ mice, ${ }^{4,5}$ the extent to which candidate pathways can compensate for impaired STAT5 activity and maintain sufficient $\mathrm{BCl}-\mathrm{x}_{\mathrm{L}}$ expression seems, at least in part, to determine the extent of anemia.

Adult PP2Ac $\alpha^{\text {TKO }}$ mice have normal steady-state hematocrit. We speculate that this is because of the different characteristics of bone marrow and fetal liver erythropoiesis. Fetal liver erythropoiesis is similar to stress erythropoiesis in that embryos have to maintain high rates of RBC generation. The embryos must produce their entire RBC mass in only a few days (E9 to E15). This leaves little erythropoietic reserve. In contrast, the adult has a remarkable erythropoietic reserve. In steady-state erythropoiesis, the rate of $\mathrm{RBC}$ production needs only match the rate of senescent RBC loss. From a molecular perspective, unlike steady-state erythropoiesis, stress and fetal liver erythropoiesis depend dramatically on the antiapoptotic effects of the EpoR-STAT5 signaling axis. Dominant-negative STAT5 increases apoptosis and inhibits growth of cultured fetal liver erythroid progenitors. ${ }^{56}$ The five STAT5-downstream genes mentioned in this study (Figure 5B) have all been implicated in fetal liver or stress erythropoiesis. Bcl-x functions as an erythroblast survival factor, as conditional gene disruption results in failed reticulocyte formation. ${ }^{57} \mathrm{Pim}-1^{-1-}$ mice exhibit decreased CFU-E number and compound Pim-1-1- $;$ Pim$2^{-1-}$ mice have microcytic anemia. ${ }^{58}$ SOCS-3 is associated with receptor kinase inhibition and degradation. OncoM-deficient mice exhibit reduced circulating erythrocytes. Finally, cis-1 provides negative feedback, par- 


\title{
A
}

\section{B}

C

D

E
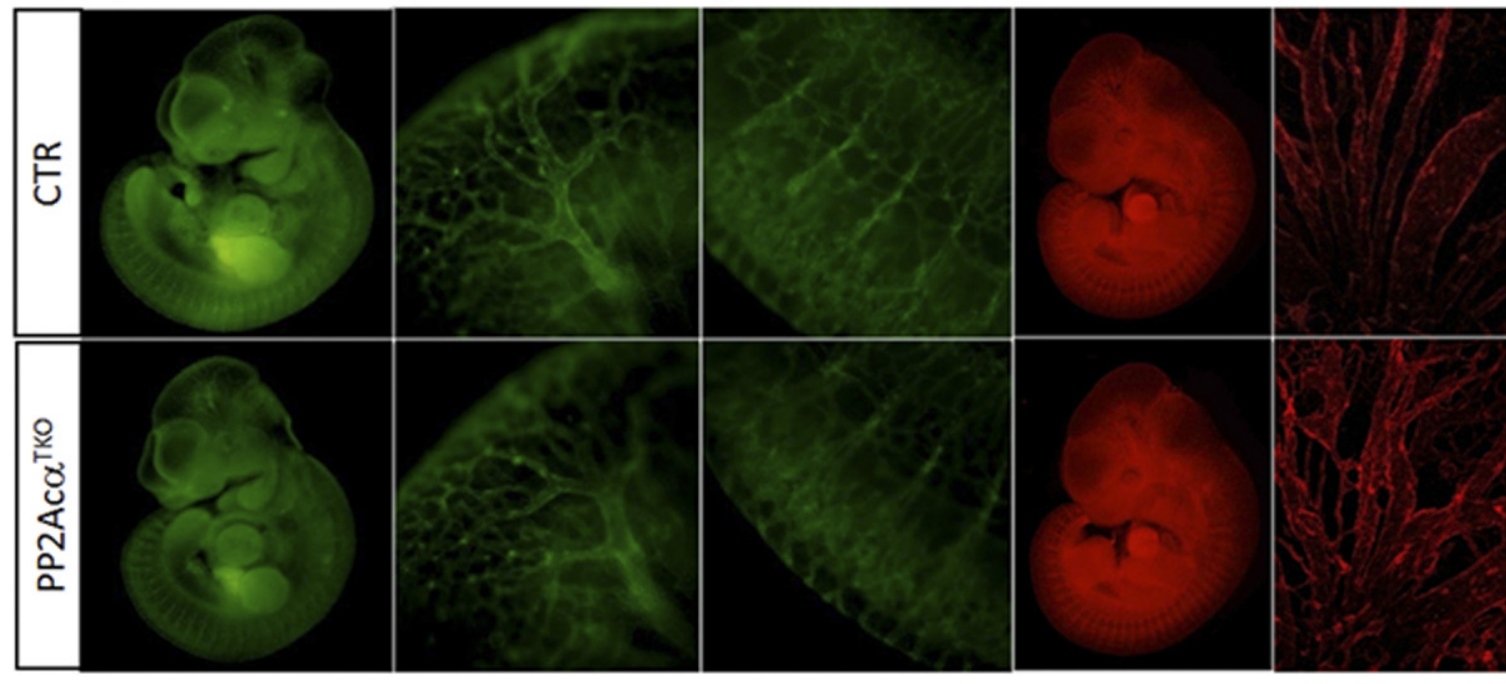

PECAM-1

endomucin

$\mathrm{F}$

$\mathrm{fl} / \mathrm{fl},+/+, \mathrm{R} 26 \mathrm{R} /+$

$\mathrm{fl} /+, \mathrm{Cre} /+, \mathrm{R} 26 \mathrm{R} /+$

$\mathrm{fl} / \mathrm{fl}, \mathrm{Cre} /+, \mathrm{R} 26 \mathrm{R} /+$

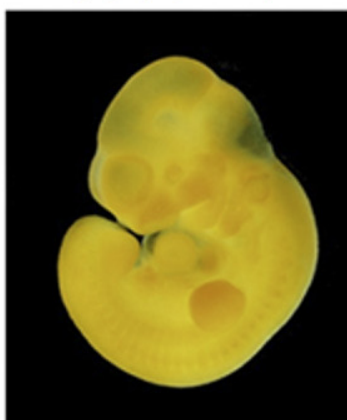

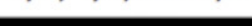

\section{Il/t, $\mathrm{Cre} / \mathrm{t}, \mathrm{R} 2 \mathrm{RR} / \mathrm{t}$}

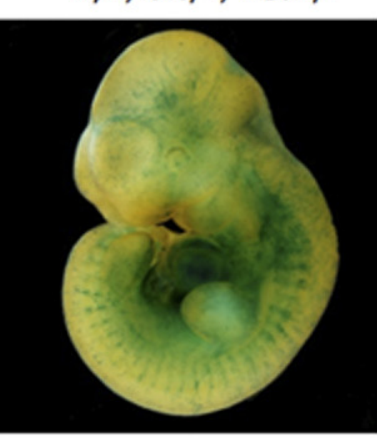

E10.5 embryo proper

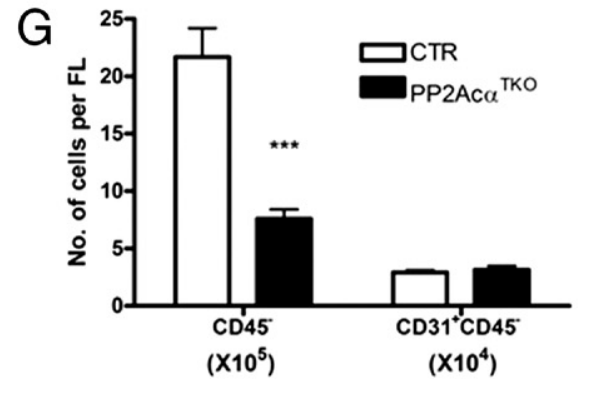

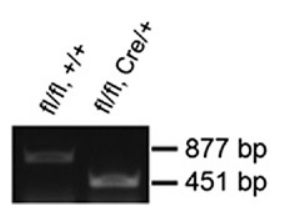

\begin{abstract}
Figure 6. No obvious vasculature defects in PP2Ac $\alpha^{\text {TKO }}$ embryos. E10.5 embryos were stained with platelet endothelial cell adhesion molecule-1 (PECAM-1; green) for whole mount (A), head (B), and somite (C) and with endomucin (red) for whole mount (D) and head blood vessels (E). F: Wholemount lacZ staining of E10.5 embryos carrying a ROSA26 allele indicates well-organized blood vasculature in PP2Ac $\alpha^{\mathrm{TKO}}$ embryos. G: The absolute number of CD $45^{-}$and $\mathrm{CD} 31^{+} \mathrm{CD} 45^{-}$cells from CTR and PP2Ac $\alpha^{\text {TKO }}$ fetal livers (FLs) was calculated ( $n=7$; ${ }^{*}$ ***: $P<0.001$; average \pm SEM). H: RT-PCR was performed to verify PP2Ac $\alpha$ mRNA in sorted $\mathrm{CD} 31^{+} \mathrm{CD} 45^{-}$cells in fetal livers. The cDNA containing exons 2 to 7 was amplified with "RNA-EXdel" primers.
\end{abstract}

tially via inhibition of JAK2 at activated EpoR complexes. ${ }^{44,45}$ However, in the present study, only $\mathrm{BCl}-\mathrm{X}_{\mathrm{L}}$ was found to be down-regulated as a result of decreased tyrosine phosphorylation of STAT5 (pY694) (Figure 5B).

\section{PP2A Functions as a Multitarget Phosphatase}

The phenotype of PP2Ac $\alpha^{\text {TKO }}$ mice is more severe than several STAT5 or Bcl-x knockout models. Although STAT5 ${ }^{\triangle N}$ mice, which still encode an N-terminally truncated and partially functional STAT5 protein, are embryonic anemic, they can be born and recover from anemia.
Adult STAT5 ${ }^{\triangle N}$ mice have a normal basal hematocrit but are impaired in recovery from anemia-promoting chemical stress. ${ }^{4,5}$ STAT5a/b-null mice, which are completely null of STAT5a/b, are more than $99 \%$ perinatal lethal due to severe anemia combined with other unidentified physiologic defects. However, the survival ratio of STAT5a/bnull mice at $\mathrm{E} 18.5$ is $100 \% .{ }^{59,60} \mathrm{BCl}-\mathrm{x}$-deficient mice die at approximately E13, showing extensive apoptosis in postmitotic, immature neurons of the developing brain, spinal cord, and dorsal root ganglia and in immature erythroid cells in the fetal liver. ${ }^{57}$ To explain the discrepancy between the present model and others, it should be 
borne in mind that for those key and multitargeting proteins, such as PP2A holoenzyme, one cannot attribute their effects to just one, or even several, downstream molecules. The phenotype we observe is likely the combined result of broad signaling pattern changes of multiple PP2A substrates. Genetic modification of PP2A itself should yield more severe phenotypes than modification of any single downstream gene.

\section{PP2Ac $\alpha$ Is Nonessential for Primitive Erythropoiesis and Early Embryonic Vasculature}

There are two waves of embryonic erythropoiesis, each with distinctive features. Primitive erythropoiesis occurs in the yolk sac at approximately E7.5. Primitive RBCs are predominantly nucleated and express embryonic hemoglobins ( $\varepsilon$ and $\beta \mathrm{H} 1$ ). Definitive erythropoiesis takes place in the fetal liver at approximately E10, generating smaller, adult-type, enucleated RBCs that express adult hemoglobins $\left(\beta^{\text {maj/min }}\right.$ and $\left.\alpha\right)$. PP2Ac $\alpha^{\text {TKO }}$ embryos showed impaired fetal liver, but normal yolk sac erythropoiesis, as indicated by comparable expression of primitive globins in both samples (Figure 3F). Consistent with the present data, embryos deficient for STAT5 or Bcl-x have not been reported to have primitive erythropoiesis defects, indicating that STAT5-BCl- $\mathrm{X}_{\mathrm{L}}$ signaling is not crucial for primitive erythropoiesis. However, Xenopus STAT5 has been shown to act as a repressor of primitive erythropoiesis and to function epistatically to fibroblast growth factor signaling. ${ }^{61}$

The finding that PP2Ac $\alpha^{\text {TKO }}$ embryos show no obvious early embryonic vasculature defects was unexpected. Consistent with the present observations, however, basal PP2A activity in skeletal microvascular endothelial cells is not high, despite the abundance of the protein in this tissue. ${ }^{62}$ This reported low PP2A activity correlates with the tyrosine-phosphorylated state of PP2Ac. In this case, the partially diminished PP2A activity may not be sufficient to induce embryonic vascular defects in PP2Ac $\alpha^{\text {TKO }}$ embryos.

Another explanation for normal primitive erythropoiesis and early embryonic vascular development in $\mathrm{PP} 2 \mathrm{Ac} \alpha^{\mathrm{TKO}}$ embryos is the redundancy by $\mathrm{PP} 2 \mathrm{Ac} \beta$, which shares $97 \%$ primary sequence similarity with PP2Ac $\alpha{ }^{13,20}$ Nevertheless, without reliable antibodies to distinguish between these two isoforms, it is difficult to determine to what extent PP2Ac $\beta$ can compensate for PP2Ac $\alpha$ in these two processes.

\section{Acknowledgments}

We thank Dr. Xingxu Huang and Dr. Ying Xu (Model Animal Research Center of Nanjing University, Nanjing, China) for their useful suggestions, and Dr. Hu Zeng (Model Animal Research Center of Nanjing University, Nanjing, China), Dr. Yu Lan (Institute of Biotechnology, Beijing, China) and Ms. Qiuting Feng (Model Animal Research Center of Nanjing University, Nanjing, China) for their technical help.

\section{References}

1. Richmond TD, Chohan M, Barber DL: Turning cells red: signal transduction mediated by erythropoietin. Trends Cell Biol 2005, 15:146-155

2. Koury MJ, Bondurant MC: Erythropoietin retards DNA breakdown and prevents programmed death in erythroid progenitor cells. Science 1990, 248:378-381

3. Wu H, Liu X, Jaenisch R, Lodish HF: Generation of committed erythroid BFU-E and CFU-E progenitors does not require erythropoietin or the erythropoietin receptor. Cell 1995, 83:59-67

4. Socolovsky M, Nam H, Fleming MD, Haase VH, Brugnara C, Lodish HF: Ineffective erythropoiesis in Stat $5 \mathrm{a}(-/-) 5 \mathrm{~b}(-/-)$ mice due to decreased survival of early erythroblasts. Blood 2001, 98:3261-3273

5. Socolovsky M, Fallon AE, Wang S, Brugnara C, Lodish HF: Fetal anemia and apoptosis of red cell progenitors in Stat5a-/-5b-/mice: a direct role for Stat5 in Bcl-X(L) induction. Cell 1999, 98:181191

6. Gregoli PA, Bondurant MC: The roles of $\mathrm{BCl}-\mathrm{X}(\mathrm{L})$ and apopain in the control of erythropoiesis by erythropoietin. Blood 1997, 90:630-640

7. Motoyama N, Kimura T, Takahashi T, Watanabe T, Nakano T: Bcl-x prevents apoptotic cell death of both primitive and definitive erythrocytes at the end of maturation. J Exp Med 1999, 189:1691-1698

8. Motoyama N, Wang F, Roth KA, Sawa H, Nakayama K, Negishi I, Senju S, Zhang Q, Fujii S, et al: Massive cell death of immature hematopoietic cells and neurons in Bcl-x-deficient mice. Science 1995, 267:1506-1510

9. Boogaerts M, Mittelman M, Vaupel P: Beyond anaemia management: evolving role of erythropoietin therapy in neurological disorders, multiple myeloma and tumour hypoxia models. Oncology 2005, 69(Suppl 2):22-30

10. List A, Kurtin S, Roe DJ, Buresh A, Mahadevan D, Fuchs D, Rimsza L, Heaton R, Knight R, Zeldis JB: Efficacy of lenalidomide in myelodysplastic syndromes. N Engl J Med 2005, 352:549-557

11. Lacombe C: Resistance to erythropoietin. N Engl J Med 1996, 334 660-662

12. Hunter T: Signaling-2000 and beyond. Cell 2000, 100:113-127

13. Janssens V, Goris J: Protein phosphatase 2A: a highly regulated family of serine/threonine phosphatases implicated in cell growth and signalling, Biochem J 2001, 353:417-439

14. Thompson CB: Apoptosis in the pathogenesis and treatment of disease. Science 1995, 267:1456-1462

15. Su JH, Deng G, Cotman CW: Bax protein expression is increased in Alzheimer's brain: correlations with DNA damage. Bcl-2 expression, and brain pathology. J Neuropathol Exp Neurol 1997, 56:86-93

16. Mumby M: PP2A: unveiling a reluctant tumor suppressor. Cell 2007, 130:21-24

17. Marshall M, Anilkumar N, Layland J, Walker SJ, Kentish JC, Shah AM, Cave AC: Protein phosphatase 2A contributes to the cardiac dysfunction induced by endotoxemia. Cardiovasc Res 2009, 82:67-76

18. Bize I, Guvenc B, Robb A, Buchbinder G, Brugnara C: Serine/threonine protein phosphatases and regulation of $\mathrm{K}-\mathrm{Cl}$ cotransport in human erythrocytes. Am J Physiol 1999, 277:C926-C936

19. Virshup DM: Protein phosphatase 2A: a panoply of enzymes. Curr Opin Cell Biol 2000, 12:180-185

20. Arino J, Woon CW, Brautigan DL, Miller TB Jr., Johnson GL: Human liver phosphatase 2A: CDNA and amino acid sequence of two catalytic subunit isotypes. Proc Natl Acad Sci U S A 1988, 85:4252-4256

21. Khew-Goodall $Y$, Hemmings BA: Tissue-specific expression of mRNAs encoding $\alpha$-and $\beta$-catalytic subunits of protein phosphatase 2A. FEBS Lett 1988, 238:265-268

22. Khew-Goodall $Y$, Mayer RE, Maurer F, Stone SR, Hemmings BA: Structure and transcriptional regulation of protein phosphatase $2 \mathrm{~A}$ catalytic subunit genes. Biochemistry 1991, 30:89-97

23. Gotz J, Probst A, Ehler E, Hemmings B, Kues W: Delayed embryonic lethality in mice lacking protein phosphatase $2 \mathrm{~A}$ catalytic subunit $\mathrm{C} \alpha$. Proc Natl Acad Sci U S A 1998, 95:12370-12375

24. Schlaeger TM, Mikkola HK, Gekas C, Helgadottir HB, Orkin SH: Tie2Cre-mediated gene ablation defines the stem-cell leukemia gene (SCL/tal1)-dependent window during hematopoietic stem-cell development. Blood 2005, 105:3871-3874

25. Koni PA, Joshi SK, Temann UA, Olson D, Burkly L, Flavell RA: Conditional vascular cell adhesion molecule 1 deletion in mice: impaired lymphocyte migration to bone marrow. J Exp Med 2001, 193:741-754 
26. Soriano P: Generalized lacZ expression with the ROSA26 Cre reporter strain. Nat Genet 1999, 21:70-71

27. Zang H, Sato K, Nakajima H, McKay C, Ney PA, Ihle JN: The distal region and receptor tyrosines of the Epo receptor are non-essential for in vivo erythropoiesis. EMBO J 2001, 20:3156-3166

28. Perez LE, Desponts C, Parquet N, Kerr WG: SH2-inositol phosphatase 1 negatively influences early megakaryocyte progenitors. PLoS One 2008, 3:e3565

29. Kutcher ME, Klagsbrun M, Mamluk R: VEGF is required for the maintenance of dorsal root ganglia blood vessels but not neurons during development. FASEB J 2004, 18:1952-1954

30. Hamaguchi I, Huang XL, Takakura N, Tada J, Yamaguchi Y, Kodama $\mathrm{H}$, Suda T: In vitro hematopoietic and endothelial cell development from cells expressing TEK receptor in murine aorta-gonad-mesonephros region. Blood 1999, 93:1549-1556

31. Hsu HC, Ema H, Osawa M, Nakamura Y, Suda T, Nakauchi H: Hematopoietic stem cells express Tie-2 receptor in the murine fetal liver. Blood 2000, 96:3757-3762

32. Takakura N, Huang XL, Naruse T, Hamaguchi I, Dumont DJ, Yancopoulos GD, Suda T: Critical role of the TIE2 endothelial cell receptor in the development of definitive hematopoiesis. Immunity 1998, 9:677-686

33. Springer T, Galfre G, Secher DS, Milstein C: Monoclonal xenogeneic antibodies to murine cell surface antigens: identification of novel leukocyte differentiation antigens. Eur J Immunol 1978, 8:539-551

34. Ikuta K, Kina T, MacNeil I, Uchida N, Peault B, Chien YH, Weissman IL: A developmental switch in thymic lymphocyte maturation potential occurs at the level of hematopoietic stem cells. Cell 1990, 62:863-874

35. Neubauer H, Cumano A, Muller M, Wu H, Huffstadt U, Pfeffer K: Jak2 deficiency defines an essential developmental checkpoint in definitive hematopoiesis. Cell 1998, 93:397-409

36. Ikuta K, Weissman IL: Evidence that hematopoietic stem cells express mouse c-kit but do not depend on steel factor for their generation. Proc Natl Acad Sci U S A 1992, 89:1502-1506

37. Whitelaw E, Tsai SF, Hogben P, Orkin SH: Regulated expression of globin chains and the erythroid transcription factor GATA-1 during erythropoiesis in the developing mouse. Mol Cell Biol 1990, 10:6596-6606

38. Wu H, Klingmuller $\mathrm{U}$, Besmer $\mathrm{P}$, Lodish HF: Interaction of the erythropoietin and stem-cell-factor receptors. Nature 1995, 377:242-246

39. Nocka K, Majumder S, Chabot B, Ray P, Cervone M, Bernstein A, Besmer P: Expression of $\mathrm{c}-$ kit gene products in known cellular targets of $\mathrm{W}$ mutations in normal and $\mathrm{W}$ mutant mice-evidence for an impaired c-kit kinase in mutant mice. Genes Dev 1989, 3:816-826

40. Fisher JW: Erythropoietin: physiology and pharmacology update. Exp Biol Med (Maywood) 2003, 228:1-14

41. Johnson GR, Moore MA: Role of stem cell migration in initiation of mouse foetal liver haemopoiesis. Nature 1975, 258:726-728

42. Kelley LL, Koury MJ, Bondurant MC, Koury ST, Sawyer ST, Wickrema A: Survival or death of individual proerythroblasts results from differing erythropoietin sensitivities: a mechanism for controlled rates of erythrocyte production. Blood 1993, 82:2340-2352

43. Pircher TJ, Zhao S, Geiger JN, Joneja B, Wojchowski DM: Pim-1 kinase protects hematopoietic FDC cells from genotoxin-induced death. Oncogene 2000, 19:3684-3692

44. Sasaki A, Yasukawa H, Shouda T, Kitamura T, Dikic I, Yoshimura A: CIS3/SOCS-3 suppresses erythropoietin (EPO) signaling by binding the EPO receptor and JAK2. J Biol Chem 2000, 275:29338-29347

45. Jegalian AG, Wu H: Differential roles of SOCS family members in EpoR signal transduction. J Interferon Cytokine Res 2002, 22:853-860

46. Yoshimura A, Ichihara M, Kinjyo I, Moriyama M, Copeland NG, Gilbert DJ, Jenkins NA, Hara T, Miyajima A: Mouse oncostatin M: an imme- diate early gene induced by multiple cytokines through the JAK-STAT5 pathway. EMBO J 1996, 15:1055-1063

47. Gonzalez-Garcia M, Perez-Ballestero R, Ding L, Duan L, Boise LH, Thompson CB, Nunez G: Bcl-XL is the major bcl-x mRNA form expressed during murine development and its product localizes to mitochondria. Development 1994, 120:3033-3042

48. Graupera M, Guillermet-Guibert J, Foukas LC, Phng LK, Cain RJ, Salpekar A, Pearce W, Meek S, Millan J, Cutillas PR, Smith AJ, Ridley AJ, Ruhrberg C, Gerhardt H, Vanhaesebroeck B: Angiogenesis selectively requires the $\mathrm{p} 110 \alpha$ isoform of PI3K to control endothelial cell migration. Nature 2008, 453:662-666

49. Alvarado-Kristensson M, Andersson T: Protein phosphatase 2A regulates apoptosis in neutrophils by dephosphorylating both p38 MAPK and its substrate caspase 3. J Biol Chem 2005, 280:6238-6244

50. Deng X, Ito T, Carr B, Mumby M, May WS Jr.: Reversible phosphorylation of $\mathrm{Bcl} 2$ following interleukin 3 or bryostatin 1 is mediated by direct interaction with protein phosphatase 2A. J Biol Chem 1998, 273:34157-34163

51. Ruvolo PP, Deng X, Ito T, Carr BK, May WS: Ceramide induces Bcl2 dephosphorylation via a mechanism involving mitochondrial PP2A J Biol Chem 1999, 274:20296-20300

52. Santoro MF, Annand RR, Robertson MM, Peng YW, Brady MJ, Mankovich JA, Hackett MC, Ghayur T, Walter G, Wong WW, Giegel DA: Regulation of protein phosphatase $2 \mathrm{~A}$ activity by caspase-3 during apoptosis. J Biol Chem 1998, 273:13119-13128

53. Fang W, Rivard JJ, Mueller DL, Behrens TW: Cloning and molecular characterization of mouse bcl-x in B and T lymphocytes. J Immunol 1994, 153:4388-4398

54. Boise LH, Gonzalez-Garcia M, Postema CE, Ding L, Lindsten T, Turka LA, Mao X, Nunez G, Thompson CB: Bcl-x, a bcl-2-related gene that functions as a dominant regulator of apoptotic cell death. Cell 1993, 74:597-608

55. Gregory T, Yu C, Ma A, Orkin SH, Blobel GA, Weiss MJ: GATA-1 and erythropoietin cooperate to promote erythroid cell survival by regulating bcl-xL expression. Blood 1999, 94:87-96

56. Chida D, Miura O, Yoshimura A, Miyajima A: Role of cytokine signaling molecules in erythroid differentiation of mouse fetal liver hematopoietic cells: functional analysis of signaling molecules by retrovirusmediated expression. Blood 1999, 93:1567-1578

57. Wagner KU, Claudio E, Rucker EB III, Riedlinger G, Broussard C, Schwartzberg PL, Siebenlist U, Hennighausen L: Conditional deletion of the Bcl-x gene from erythroid cells results in hemolytic anemia and profound splenomegaly. Development 2000, 127:4949-4958

58. Hammerman PS, Fox CJ, Birnbaum MJ, Thompson CB: Pim and Akt oncogenes are independent regulators of hematopoietic cell growth and survival. Blood 2005, 105:4477-4483

59. Cui Y, Riedlinger G, Miyoshi K, Tang W, Li C, Deng CX, Robinson GW, Hennighausen L: Inactivation of Stat5 in mouse mammary epithelium during pregnancy reveals distinct functions in cell proliferation, survival, and differentiation. Mol Cell Biol 2004, 24:8037-8047

60. Yao Z, Cui Y, Watford WT, Bream JH, Yamaoka K, Hissong BD, Li D, Durum SK, Jiang Q, Bhandoola A, Hennighausen L, O'Shea JJ: Stat $5 \mathrm{a} / \mathrm{b}$ are essential for normal lymphoid development and differentiation. Proc Natl Acad Sci U S A 2006, 103:1000-1005

61. Schmerer M, Torregroza I, Pascal A, Umbhauer M, Evans T: STAT5 acts as a repressor to regulate early embryonic erythropoiesis. Blood 2006, 108:2989-2997

62. Wu F, Wilson JX: Peroxynitrite-dependent activation of protein phosphatase type 2A mediates microvascular endothelial barrier dysfunction. Cardiovasc Res 2009, 81:38-45 